7. Отчет о проведении государственных выпускных экзаменов по заочному отделению русского языка и литературы Черниговского учительского института (1955). - ДАЧО, ф. Р-1495, оп.1, спр. 17, арк. 1-20.

References

1. Godovoj otchet o rabote kafedry pedagogiki CHernigovskogo uchitel'skogo instituta za 1951/52 uchebnyj god, sostavlenyj Lvovom I. P. (1952). DACHO, f.R-1495, op.1, spr. 15, 26 .

2. Godovoj otchet o rabote kafedry pedagogiki CHernigovskogo uchitelskogo instituta za 1952/1953 uchebnyj god, sostavlennyj Lvovom I. P. (1953). - DACHO, f. R-1495, op.1, spr. 16, 69.

3. Informacionnaya zapiska zaveduyushchego kafedroj pedagogiki CHernigovskogo uchitel'skogo instituta Lvova I. P. o podgotovke kafedry $k$ novomu uchebnomu godu v svyazi s zamechaniyami komissii, obsledovannoj raboty kafedry (1950). - DACHO, f. R-1495, op.1, spr. 14, 8.

4. Pismo Ministerstva prosveshcheniya USSR o postanovlenii NK USSR $\mathrm{CKKP}(\mathrm{b}) \mathrm{U}$ ot 12 fevralya $1946 \mathrm{~g}$. ob ustanovlenii premii imeni K. D. Ushinskogo za nauchnye trudy po pedagogike, postanovlenie Soveta CHernigovskogo pedinstituta o rezul'tatah zimnej ekzamenacionnoj sessii
1953 g., protokol zasedaniya kafedry pedagogiki CHernigovskogo uchitel'skogo instituta i tezisy vystupleniya na nem I. P. Lvova (1951-1954). DACHO, f. R-1495, op.1, spr. 11, 12

5. Plan raboty kafedry pedagogiki CHernigovskogo uchitelskogo instituta na II semestr 1950-1951 uchebnogo goda i raboty $v$ bazovoj shkole na I polugodie 1952-1953 uchebnogo goda (1950-1953). - DACHO, f. R-1495, op. 1 , spr. 12,4

6. O sostoyanii pedagogicheskoj nauki i merah likvidacii ee otstavaniya rezolyuciya po dokladu prezidenta Akademii pedagogicheskih nauk RSFSR I. A. Kairova na soveshchanii po voprosam pedagogiki i plan meropriyatij APN v svyazi s zadachami, vydvinutymi soveshchaniem; doklad zaveduyushchego kafedroj pedagogiki CHernigovskogo pedinstituta docenta Lvova I. P. na zasedanii Soveta instituta po obsuzhdeniyu etih dokumentov (1955). - DACHO, f. R-1495, op.1, spr. 10, 32.

7. Otchet o provedenii gosudarstvennyh vypusknyh ekzamenov po zaochnomu otdeleniyu russkogo yazyka i literatury CHernigovskogo uchitelskogo instituta (1955). - DACHO, f. R-1495, op.1, spr. 17, 20.

Надійшла до редколегії 07.12.19

A. Ostapenko, postgraduate student

Taras Shevchenko National University of Kyiv, Kyiv, Ukraine

\title{
MANAGEMENT ACTIVITY OF IP LVOV IN THE POSITION OF HEAD OF THE DEPARTMENT OF PEDAGOGY OF THE CHERNIGIV PEDAGOGICAL INSTITUTE (1952-1958)
}

The article shows I. P. Lvov, chairman of the Department for pedagogy of Chernihiv Pedagogical Institute.

I. P. Lvov worked as the Head of the Department of Pedagogy from 1952 to 1958 . He developed didactic materials on pedagogy, logic and psychology. The curriculum for the second semester was analyzed, where the main tasks were students' educational work, advanced training of teachers and realization of public works under the teachers.

At the faculty meeting, the lecturers approved the Individual work plans of the members of the department, monitoring the lectures and pedagogical lessons from the point of view of scientific and methodological execution, control over the work of a laboratory assistant, review and approval of the work plan of pedagogical practice of students.

I. P. Lviv had intended to purchase a separate room for conducting psychological experiments. Unfortunately, the intention failed for unknown reasons. He controlled the quality of lectures and seminars on pedagogy, lectures on psychology, and reported on the visit by the directorate of the institute and individual members of the chair they reviewed.

In 1952, a pedagogical circle was formed at the department of pedagogy. I. P. Lviv was group leader of the circle at one of the meetings read a report "Modern problems of restructuring the science of psychology in the academician I. P. Pavlov".

I. P. Lviv appreciated the work of the laboratory assistant of the department of G. P. Svirid, pointing to her faithful discharge of her duties: providing students with educational and recommended literature.

The content of the documents of I. P. Lvov on an administrative post was analyzed and he was found that he made some comments in the report at the meeting of the pedagogy department of the Chernihiv Pedagogical Institute, as well as at the meeting of the Institute council concerning the issues that were in the report "On the condition of pedagogical science and eliminating its backlog" on the resolution of I. A. Kairov.

In $1955 \mathrm{I}$. P. Lvov was the head of the commission on State examinations of the correspondence department of the Russian language and literature of the Chernihiv Pedagogical Institute. Analysis of students' answers in pedagogy, according to I. P. Lvov, showed that most were positive answers, but some students had satisfactory grades, they did not possess good material in pedagogy.

Keywords: resolution, lecturer, Head of the Department of Pedagogy, I. P. Lviv.

удК 316.37.013.78

DOI: https://doi.org/10.17721/2415-3699.2020.12.10

О. Поляк, канд. пед. наук, доц. Київський національний університет імені Тараса Шевченка, Київ

\section{РОзвИТОК СОЦІОЛОГІЧнОї ОСвІтИ В УКРАїнІ}

Досліджено становлення соціології як науки та навчальної дисципліни, доведено явище значного впливу індивідуальних рис і знань творців соціології на їі розвиток на початковій стадії, досліджено причини відмін в еволюції соціології в Західній Європі, США, $і$ Східній Європі. Запропоновані вдосконалення цього періоду в підручниках для ЗВО.

Виявлено помилковість поширеного в сучасних підручниках твердження про відсутність соціологічних досліджень у радянському Союзі. Вказано на факти їхнього розвитку у 20-30-х рр. у формі пошуку "наукові організації праці" та у 60-70-х рр. у формі здійснення "соціальних передбачень".

Вивчено відновлення соціології і формування соціологічної освіти в незалежній Україні. Досліджено навчальні плани й інші аспекти підготовки фахівців соціологічних профілів у ЗВО, вказано на існування неузгодженості термінології формулювань у дипломах зВО з офіційним Класифікатором професій.

Ключові слова: сочіологічна думка, сочіологія, сочіологічна освіта.

Постановка проблеми. Аналіз наукових праць із педагогіки та соціології засвідчив, що термін "соціологічна освіта в Україні" в них не зустрічався жодного разу. Зокрема не здійснювалось системне дослідження педагогічних і загальнонаукових проблем розвитку сектору соціологічної освіти.

Натепер прискорився процес модернізації закладів вищої освіти та іїі інтеграції до європейського освітнього простору. Передбачено виконання комплексу завдань щодо реформування системи вищої освіти в Україні, зокрема:
- модернізації системи вищої освіти, системи і структури кваліфрікацій

- удосконалення змісту вищої освіти та організації навчального процесу.

Реалізація цих завдань у системі закладів вищої освіти (ЗВО) України сприятиме досягненню основної мети - підготовки висококваліфікованих фахівців, які будуть конкурентоспроможними на національному, європейському та світовому ринках праці. 
Усебічний аналітико-узагальнюючий огляд вітчизняних і зарубіжних літературних джерел, дисертацій педагогів і представників інших наук на соціологічні теми, що захищаються в Україні з початку 1990-х р., свідчить, що основна їхня кількість припадає на період введення спеціальності "соціальна педагогіка" (13.00.05). Однак системно не досліджувався і взагалі не був об'єктом дослідження весь сектор соціологічної освіти. Це дало підстави для висновку, що стан наукової розробки вказаної теми не може вважатись задовільним і потребує науково-практичного обґрунтування й всебічного дослідження.

За період 1986-2019 р. в Україні сформувався значний за обсягом і навчальним потенціалом сектор соціологічної освіти, який, однак, ще не був досліджений науковцями-педагогами і не фогурував у тематиці кандидатських і докторських дисертацій.

3 огляду на необхідність виконання вищезазначених завдань, ми вважаємо актуальним і закономірним дослідження еволюції соціології як науки й навчальної дисципліни в Україні та за їі межами, є метою цього дослідження.

Аналіз останніх досліджень і публікацій. Значною науковою цінністю для дослідження є праці таких вітчизняних дослідників історії й основних сутнісних рис загальної і прикладної соціології, як В. Волович, І. Гавриленко, М. Головатий, І. Звєрєва, А. Капська, М. Лукашевич, А. Некрасов, В. Піча, О. Погорілий, А. Ручка, В.Танчер, С. Хлєбік, М. Юрій, О. Якуба, а також зарубіжних - В. Бачинін, В. Добреньков, А. Кравченко, Е. Гіденс, Н.Смелзер, П. Штомпка q ін.

Теоретичні засади й положення методології порівняльної педагогіки висвітлюють науковці Н. Абашкіна, Б. Вульфсон, В. Кларін, К. Корсак, 3. Малькова, В. Пилиповський, Л. Пуховська, А. Сбруєва й ін.; загальні концепції фрілософрії освіти і науки, засади виховання й навчання досліджують В. Андрущенко, І. Бех, С. Гончаренко, І. Зязюн, В. Лутай, М. Максюта й ін.; концептуальні положення щодо організації та розвитку системи післядипломної професійної освіти, поглибленої фахової підготовки, безперервної освіти визначають В. Бондар,

Р. Бойко, І. Жерносек, Г. Козлакова, М. Красовицький, С. Крисюк, А. Кузьмінський, В. Маслов, В. Майборода, В. Олійник, Н. Протасова, Т. Сущенко.

Сучасні теорії суспільного розвитку й участі освітньонаукового комплексу в забезпеченні суспільного прогресу досліджені у працях таких науковців, як М. Амосов, А. Гальчинський, О. Білорус, В. Луговий, С. Льовочкін, В. Семиноженко, Е. Тоффрлер, Е. Фор, Ф. Фукуяма.

Первинні соціологічні уявлення і знання (період деінституціоналізованої соціології) поділено на три частини різного обсягу й неодночасної появи: 1) повсякденний досвід; 2) художні відтворення та вияви; 3) філософська рефлексія, що претендувала на виявлення й дослідження загальних законів буття та поступово набула рис науковості. Здійснено детальний аналіз кожної з них.

Питання часової межі виокремлення соціології в наукову дисципліну залишається дискусійним і донині. Її творцями вважають Шарля Луї Монтеск'є, Клода Сен Симона, Огюста Конта, Карла Маркса, Еміля Дюркгейма, Герберта Спенсера, Алексіса де Токвіля, Вільфредо Парето, Макса Вебера.

Викладення основних положень. Свою увагу ми сконцентрували на перевірці власної гіпотези: народження соціології було "індивідуалізованим" процесом, позначеним впливом неповторних рис науковців, специфокою накопичених ними знань та іншими чинниками. У тексті статті наведено багато доказів справедливості цього припущення та вказано, що загалом це явище має значний виховний потенціал. Його варто активніше використовувати в навчальній літературі із соціології.
Не останню роль у розвитку й успіх соціології відіграли також "географрія" й "політика". Своє інституціональне визнання соціологія отримує в найбільш демократичній на той час країні. Саме у США в 1892 р. виникає перший соціологічний фракультет у Чиказькому університеті, а в 1909 р. Американська соціологічна асоціація (ASA), що є однією 3 найбільших професійних організацій соціологів.

У Європі, на батьківщині О. Конта, перша кафедра соціології створюється в 1896 р. в університеті м. Бордо, 1919 у Німеччині - у Мюнхенському університеті, де засновується "Німецька соціологічна спілка" - DsG. Визнання і статус. У Великобританії соціологія отримує визнання лише після Другої світової війни в університетах Кембриджа й Оксфорда, але спочатку виступає як соціальна антропологія чи соціальна і політична філософрія. 1920 р. у Польщі було засновано кафедру соціології в університеті у Познані й перший університетський соціологічний центр, де випускається перший польський соціологічний журналу "Соціологічний огляд", що виходить і зараз.

На міжнародному рівні організація і співпраця соціологів беруть початок із 1893 р., коли французький учений Рене Ворс заснував Міжнародний соціологічний інститут (IIS). 1949 р. виникла Міжнародна соціологічна організація (ISA), яка через півстоліття налічувала понад 3 тис. соціологів із майже 100 країн світу.

Формування української й російської соціології, що відбувалося за участі та під впливом таких науковців: М. Драгоманов, В. Липинський, М. Ковалевський, Б. Кістяківський, П. Сорокін та ін., неконформістські чи дисидентські настрої яких найчастіше були наслідком їхнього навчання чи стажування у Європі. Зовсім інші - дуже сприятливі умови - мала соціологія на теренах США. Усі соціологи США "першої хвилі" були успішними і прагматичними університетськими професорами, які не лише не повставали проти американської індивідуалістичної демократії, а й намагалися ії захистити та зміцнити (В. Самнер, Л. Уорд, Ф. Гіддінгс, А. Смолл і багато ін.).

Поширення соціології в усіх великих і середніх університетах і коледжах США, виникнення значних за розмірами й потенціалом наукових шкіл поза Чикаго в Колумбійському, Гарвардському й інших університетах відбувається в роки майже цілковитого знищення соціології у СРСР, де ця наука була відсутня в академіях наук, не існувало університетської дисципліни, а окремі дослідження соціологічного плану зрідка виконували представники інших гуманітарних наук.

Аналіз поширених в українських підручниках із соціології поглядів на історію розвитку соціології, на роль видатних персоналій, а також на особливості формування соціологічної думки на теренах Західної Європи, у США, в Україні й Росії разом із застосуванням важливої інформації із фрілософрії, психології, педагогіки, етології і (почасти) природничих наук дав змогу виявити слабкості й недоліки традиційних текстів основних підручників і по-новому висвітлити окремі вузлові питання, запропонувавши на цій основі новий навчальний матеріал для студентів.

Важливі нові аспекти виявлені у становленні соціології поза Західною Європою - спільне та відмінності між Росією, Україною та США. Здійснене порівняння їхнього суспільно-культурного й економічного "поля" і доведення того, що лише в США були порівняно сприятливі умови для появи та зміцнення соціології і як науки, і як університетської дисципліни, де діяли переважно університетські професори і організовані ними наукові школи. У Російській імперії пошук молодою людиною соціологічних знань майже завжди визначав долю дисидента. Америка успішно використала для розвитку прикладної соціології кадрові можливості Польщі й інших європейських 
держав, пояснено причини вивищення Чиказького університету як першої "соціологічної столиці".

Уже зі своїх витоків соціологія зазнавала доволі потужного впливу з боку не лише фрілософії, а й точних наук. Тому методологічна основа теоретичних і прикладних соціологічних досліджень спочатку та згодом розвивалася в руслі головних наукових методологій - класичної, некласичної (модерної) і постнекласичної (постмодерної). Вони виникали у вказаній черговості i, звичайно, на певному проміжку існували одночасно - на його початку домінував один метод, а наприкінці - інший. Визначаються прояви впливу змін природничо-наукових парадигм на становлення й розвиток сфери соціологічних досліджень. Зараз почастішали випадки застосування досягнень синергетики у вивченні соціальних систем, для передбачення можливих траєкторій розвитку політичних і економічних явищ, руху до суспільної самоорганізації чи до іншого варіанта стану соціуму після проходження ним критичної точки (точки "біфуркації").

Війни й революції спотворили нормальний розвиток соціології не лише на території України та Росії, а й Західної Європи. Успішне відновлення науки відбулося на короткий термін між світовими війнами, а в повному обсязі-у другій половині XX ст. Дослідження особливостей цього процесу й сучасної диференціації теоретичної і прикладної соціології виявило паралелі в еволюції парадигм і методології точних наук і соціології. За 200 років змінили одна одну три значні методології - класична, некласична (модерна) і постнекласична (постмодерна).

У другій половині XX ст. методологія соціології змінювалася вже не під впливом фрізики чи біології, а зрушень фрілософії, політології й інших гуманітарних наук до так званого "постмодерністського" поля, на якому постулатом стало твердження про відсутність існування будьяких соціальних законів, які були б "вічними і незмінними". У наш час наука втратила "відстороненість" і об'єктивізм, вона стала важливою ресурсо- і кадроємною частиною суспільства. За таких умов найкращим методом соціологів стає "діяльнісний" (інша назва - неофункціоналізм), у рамках якого враховують вплив на об'єкт одразу багатьох матеріальних та ідеальних чинників (це яскравий приклад звернення до синергетики).

Результатом різноманітності критеріальності під час поділу соціологів певної країни чи світу для віднесення до певної школи та суперечливості в термінологічному апараті соціології $є$ те, що представники різних країн і наукових шкіл вкладають різний зміст навіть у фундаментальні категорії, поняття і терміни. Як наслідок - виникають труднощі у процесі спроб викладу матеріалу щодо стану цієї сфери наукових знань наприкінці XX ст. чи в цей момент, і тому цілком виправданий той факт, що у вступних розділах більшості підручників їхні автори вказують засновників соціології, а надалі продовжують подібний персоналістичний підхід і під час аналізу розвитку соціології в XX ст., обмежуючись невеликою кількістю найбільш відомих у світі соціологів та описом орієнтації наукових шкіл.

У сучасних умовах найбільш перспективним серед усіх засобів соціологів стає "діяльнісний" підхід (неофункціоналізм), який спирається на ряд доцільних припущень і намагається отримати результат з одночасним урахуванням впливу на об'єкт зацікавлення одразу багатьох матеріальних та ідеальних чинників (це ми й вважаємо яскравим прикладом звернення до синергетики). Відзначимо, що й цей метод не є ідеальним, адже, поперше, за час пошуків і обчислення "підсумку усіх впливів" соціокультурне поле обов'язково зміниться, а тому результат застосовуватиметься не до актуального стану, а до того, який існував у ньому на початку досліджень; по-друге, не всі впливи мають однакову природу й інтенсивність (їхній геометричний образ - вектори з надто різними модулями), а тому висока ймовірність того, що для деяких з них необхідно застосовувати закони нелінійного векторного аналізу й інші сучасні методи.

3 аналізу історії радянської освіти випливає те, що одним із головних її завдань було викорінення релігійності. У поширених у сучасній Україні підручниках під час опису долі соціології у СРСР найчастіше наголошується факт вжиття репресивних заходів. Інколи коротко вказані головні події тих років - припинення підтримки діяльності соціологічних шкіл у Петрограді й Москві, вигнання більшості відомих соціологів, економістів і представників гуманітарних наук тощо. Частіше ж, приклади чого наводяться в тексті, вказується, що фрактично в СРСР соціологія була знищена дощенту й не існувала аж до початку перебудови М. Горбачова.

Насправді соціологічна думка й дослідження у споріднених сфрерах не зникали в СРСР ніколи. Були моменти загального інтересу, наприклад, до застосування світових досягнень з управління й діяльності, що привело до появи великої кількості центрів дослідження та впровадження "наукової організації праці". Здійснюючи найрізноманітніші педагогічно-виховні експерименти, радянські педагоги нічим не поступалися зарубіжним, а кращі $з$ них - як Л. Виготський (1896-1934), спромоглися висловити ідеї, що й зараз привертають увагу більшості педагогів і психологів світу. У статті проаналізовано життєвий шлях П. Сорокіна, який на схилі свого віку у США отримав можливість "довивчення" з урахуванням нових знань і поширення удосконалених варіантів тих ідей та уявлень, які він сформував ще до вигнання з Радянського Союзу.

Під тиском бажання майже миттєво перетворити СРСР на індустріальну державу й забезпечити масову ідеологічну підготовку підготовлених фахівців, Й. Сталін та інші більшовики реформували освіту на основі централізації управління, жорстких стандартів, повної заборони пропусків уроків і лекцій, а у сфері наук про суспільство віддали пріоритет не веберівським чи іншим кращим тогочасним теоріям, а історичному матеріалізму й подібним дисциплінам, що мали виразні переваги легкості застосування у пропаганді комуністичних поглядів серед молоді й дорослих. Соціологія за таких умов була приречена на маргінальне існування та не підтримувалася державними органами.

Потреби в теоретичних знаннях про суспільство такої великої й розвиненої держави, якою був Радянський Союз, не могли забезпечуватися історичним матеріалізмом, що мало застосовувався для розв'язання безлічі дрібних проблем. Тому, як засвідчено на багатьох прикладах, навіть у часи жорстких заборон на використання термінів "соціологія", "педологія" й інших проводилися прикладні соціологічні дослідження обмеженого обсягу, вивчався розвиток дітей, було створено державну спілку соціологів, а подалі від Москви тривала діяльність академічних та університетських соціологічних осередків.

Зокрема, масштабний соціологічний експеримент під назвою "Таганрозький проект", що за 1966-1974 р. дав величезну кількість різноманітної інформації та фактологічних матеріалів, частина з яких цікавить науковців-аналітиків і тепер. Хоча він був цілком успішним і загалом понад 20 учасників захистили дисертаційні роботи, а значна кількість представників різних наук отримали безцінний досвід виконання важливих досліджень, "замовники" з керівних партійних органів відмовилися від продовження роботи. Головна причина полягала в тому, що 
отримані соціологами дані не використовувалися для пропагандистської роботи. Приблизно такою самою була й доля набагато всеохопнішої діяльності, яка проходила під гаслом "соціальне прогнозування" та пошуки прискорених шляхів подолання всіх перешкод на початку побудови комунізму у СРСР.

Зазначається, що поява в роки хрущовської "відлиги" й діяльності досить великої кількості соціологічних підрозділів все ж не стала основою для відродження "соціології" як науки й навчальної дисципліни. Це сталося наприкінці існування СРСР - лише у 1980-х рр. відбувся повільний рух від політичного рішення ЦК КПРС до офіційного включення до навчальних планів університетів та інших 3ВО.

Першими виникли спеціальності "Прикладна соціологія", "Соціальна педагогіка", "Соціальна робота", які легше від "Соціології" можна було адаптувати до радянського класифрікатора профресій. У цьому підрозділі порівнюються відродження й розвиток соціологічної освіти в Російській Федерації та Україні. Аналізуються думки російських науковців про досягнення в цій сфері та ті значні деформації, які виникли внаслідок поспіху й орієнтації фрахівців із соціології не на державну підтримку науки, а на виконання "ринкових" замовлень підприємців, політичних партій та ін.

Значну й цілком нову інформацію отримано під час дослідження структурних і дидактичних характеристик діяльності сектору соціологічної освіти в Україні. Аналіз довідників для вступників у ЗВО України за роки незалежності дало змогу простежити еволюцію назв спеціалізацій у соціологічній освіті України й отримати дані про те, скільки ЗВО пропонували студентам ті чи інші варіанти навчання. Виявлено та проаналізовано фракт великих розбіжностей між класифікаторами професій і тим, що пропонували і пропонують ЗВО. Упровадження нового Класифікатора професій ДК 0003:2005 має викликати зміни в діяльності ЗВО України.

Висновки. Отже, виявлений факт невідповідності навчальних програм багатьох ВН3 тим рекомендаціям, що створені колективами науковців на замовлення урядових органів. Досліджено та здійснено порівняння ОПП, ОКХ і програм підготовки соціологів кількох університетів та інших ВНЗ України. Запропоновано шляхи приско- рення розвитку й удосконалення діяльності сектору соціологічної освіти у системі вітчизняної вищої освіти з урахуванням Болонського процесу й інших інтеграційних процесів, зокрема вказано на необхідність включення України у створення спільного європейського простору не лише вищої освіти, а й фундаментальних наукових досліджень, у наміри держав Європейського Союзу продовжити нарощування свого людського потенціалу через створення й акумуляцію "знань розвитку", важливою частиною яких $є$ соціологічні знання.

Список використаних джерел

1. Поляк О. В. Шляхи подолання негативних наслідків інформаційного буму в професійній підготовці і діяльності соціальних працівників // Вища освіта України. - 2004. - № 4. - С. 188-192.

2. Поляк О.В. Соціологія і соціологічна освіта в умовах ринкових перетворень // Вища освіта України. - 2006. - № 1. - С. 35-41.

3. Поляк О. В. Формування у студентів емоційної компетентності одне з завдань вищої освіти України / О. В. Поляк, Л. М. Ляшенко // Наук. зап. Ніжин. держ. ун-ту ім. М. Гоголя // Психолого-педагогічні науки. 2005. - № 3. - C. 49-53.

4. Поляк О. В. Становлення соціології поза Західною Європою - спільне і відмінності між Росією, Україною та США / О. В. Поляк // Вища освіта України. - 2006. - № 3. - Т. 2. - С. 323-330.

5. Поляк О. В. Особливості відновлення соціологічної освіти в СРСР і незалежній Україні / О. В. Поляк // Наук. зап. Ніжин. держ. ун-ту ім. М. Гоголя // Психолого-педагогічні науки. - 2007. - № 3. - С. 12-16.

6. Поляк О. В. "Трава і асфальт" або еволюція соціологічної думки на теренах Радянського Союзу / О. В. Поляк // Вища освіта України. - 2007. - № 2. - T. 2. - C. 7-10.

\section{References}

1. Poliak O. V. Ways to overcome the negative consequences of the information boom in the training and activities of social workers / O. V. Poliak // Higher Education of Ukraine. - 2004. - № 4. - P. 188-192.

2. Poliak O.V. Sociology and sociological education in the conditions of market transformations / O. V. Poliak // Higher education of Ukraine. - 2006. - № 1. - P. 35-41.

3. Poliak O. V. Formation of emotional competence in students is one of the tasks of higher education in Ukraine / O. V. Poliak, L. M. Lyashenko // Nizhyn. state un-tu them. M. Gogol // Psychological and pedagogical sciences. - 2005. - №3. - P. 49-53.

4. Poliak O. V. Formation of sociology outside Western Europe - common and differences between Russia, Ukraine and the United States / O. V. Poliak // Higher Education of Ukraine. - 2006. - № 3. - T. 2. - S. 323-330.

5. Poliak O. V. Features of the restoration of sociological education in the USSR and independent Ukraine / O. V. Poliak // Nizhyn. state un-ty them. M. Gogol // Psychological and pedagogical sciences. - 2007. - № 3. - P. 12-16.

6. Poliak O. V. "Grass and asphalt" or the evolution of sociological thought in the Soviet Union / O. V. Poliak // Higher Education of Ukraine. - 2007. № 2. - Vol. 2. - P. 7-10.

Надійшла до редколегії 18.12.19

O. Poliak, Ph.D, Associate Professor

Taras Shevchenko National University of Kyiv, Kyiv, Ukraine

\section{DEVELOPMENT OF SOCIOLOGICAL EDUCATION IN UKRAINE}

Sociology as sciences and a subject matter has been researched, the phenomenon of significant influence of individual features and knowledge of creators of sociology on its development at an initial stage has been proved, the reasons of differences in evolution of sociology in the Western Europe, the USA and in the East Europe have been analyzed. Improvements of a statement of this period in textbooks for higher schools are offered.

The inaccuracy of the statement distributed in modern textbooks about absence of sociological researches in Soviet Union is revealed. It is specified on the facts of their development in 20-30th years in the form of searches of "the scientific organization of work" and in 60-70th years as realization of "social forecasts".

Significant and completely new information was obtained during the study of structural and didactic characteristics of the sociological education sector in Ukraine. The analysis of reference books for entrants higher education institutions of Ukraine during the years of independence made it possible to trace the evolution of the names of specializations in sociological education of Ukraine and to obtain data on how many higher education institutions offer students different types of learning. The fact of great differences between the classifiers of professions and what was offered and is offered by higher education institutions has revealed and analyzed. The introduction of the new Classifier of Professions DK 0003 : 2005 should cause changes in the activities of the higher education institutions.

Ways to accelerate the development and improvement of the sociological education sector in the domestic higher education system are proposed, taking into account the Bologna process and other integration processes, in particular, the need to include Ukraine in creating a common European space Union to continue building its human potential through the creation and accumulation of "development knowledge", an important part of which is sociological knowledge.

Restoration of sociology and formation of sociological education in the USSR 80th years, development and permanent changes of sociological education in independent Ukraine is investigated. Curricula and other aspects of preparation of experts of sociology in several universities and other higher schools are investigated, is specified on existence of a nonagreement of terminology of formulations in diplomas of higher schools with the official Qualifier of trades.

Keywords: sociological thought, sociology, sociological education. 